\title{
ECONOMIC EVALUATION OF A HYDROTHERMAL LIQUEFACTION PROCESS
}

\author{
Geert Haarlemmer *,1, Morgane Briand, Anne Roubaud, Julien Roussely and \\ Maxime Déniel
}

University Grenoble Alpes, CEA, LITEN, DTBH/SBRT/LTCB, F-38000, Grenoble, France

Article Info:

Received:

30 January 2018

Revised:

11 June 2018

Accepted:

30 July 2018

Available online:

10 September 2018

Keywords:

Food processing waste

Sewage sludge

Hydrothermal liquefaction

Biocrude

Technical-economic evaluation

\begin{abstract}
Wet waste streams include a wide variety of products such as food processing residues, sewage sludge, but also the organic fraction of municipal solid waste. Hydrothermal liquefaction is a thermochemical conversion in hot compressed water that produces a hydrophobic product. This paper gives presents how hydrothermal liquefaction can produce a biocrude or a heavy fuel oil from blackcurrant pomace, grape marc and sewage sludge. The paper presents experimental results as well as a technical and economic evaluation of the process. The results from hydrothermal liquefaction depend on the resource. Typical biocrude yield is $50 \%$ of the dry resource while bio-oil yield can be up to $25 \%$. High ash resources are however less interesting for this technology. The production costs are high compared to their fossil counterparts but gate fees in the order of 50 to $130 €$ tonne $^{-1}$ could ensure economic competitiveness compared to fossil fuels.
\end{abstract}

\section{INTRODUCTION}

Waste streams are an extremely variable and diffuse resource. Examples include sewage sludge, food processing residues and the organic part of municipal solid waste. Humidity typically varies from 50 to $90 \%$. Basic incineration but also more advanced techniques such as gasification and pyrolysis, are interesting for dry feedstocks but lose much of their interest when the humidity of the resource is higher than $50 \%$. Dewatering and drying is possible for most feedstocks but at a significant cost. These wet waste streams are often used or abandoned in low value applications such as composting, incineration or landfill. Many environmental problems are associated to those waste streams such as bad odours but also due to the production of secondary pollutants such as dioxins during incineration.

Current disposal routes include composting, anaerobic digestion but also landfill and incineration (often after drying). Hydrothermal Liquefaction (HTL) is an alternative waste treatment that makes it possible to produce liquid fuels potentially replacing fossil fuels. Hydrothermal liquefaction produces a biocrude that can be further upgraded to biofuels. This paper shows how the operation of HTL plants can be made economically feasible.

Hydrothermal liquefaction converts biomass in hot compressed water into a biocrude. This biocrude is an oily material containing bio-oil and char. Hydrothermal liquefaction has been known for some time. The devel- opments started simultaneously in Europe (Goudriaan \& Peferoen, 1990) and in the United States (Elliott \& Schiefelbein, 1989). The conversion takes place at temperatures between 300 and $400^{\circ} \mathrm{C}$ and at pressures above the saturation pressure to ensure that water remains in the liquid phase, typically above 100 bar. Under these conditions the ionisation of water increases while its polarity decreases (Kruse \& Dahmen, 2015), favouring depolymerisation and dehydration of biomass polymers to produce hydrophobic compounds.

Figure 1 shows a typical resource, black currant pomace, an autoclave batch reactor and the biocrude obtained. The Heating Value of the biocrude is typically 30-35 MJ $\mathrm{kg}^{-1}$ whereas the original biomass has heating values in the 15-21 $\mathrm{MJ} \mathrm{kg}^{-1}$ range. This biocrude can either be used directly as a combustible liquid, fed into a refinery as crude oil (Buisonjé et al., 2010), or it can be upgraded to a diesel type biofuel (Zhu et al., 2014). The initial development of the technology in the 1970s has been hampered by low oil prices in the 1990s but also by technical difficulties and the increasing cost of biomass. Increasing oil prices in the early years 2000 lead to a regain in interest. The application of hydrothermal liquefaction to wet waste streams can procure a new momentum for this technology. Traditional HTL laboratories such as PNNL are actively working on this subject as well as many newcomers.

The chemical composition of the resource plays a major role in the product yield and quality as has been shown by
* Corresponding author:

Geert Haarlemmer

email: geert.haarlemmer@cea.fr
Detritus / Volume 03 - 2018 / pages 84-92

https://doi.org/10.31025/2611-4135/2018.13695

(c) 2018 Cisa Publisher. Open access article under CC BY-NC-ND license 

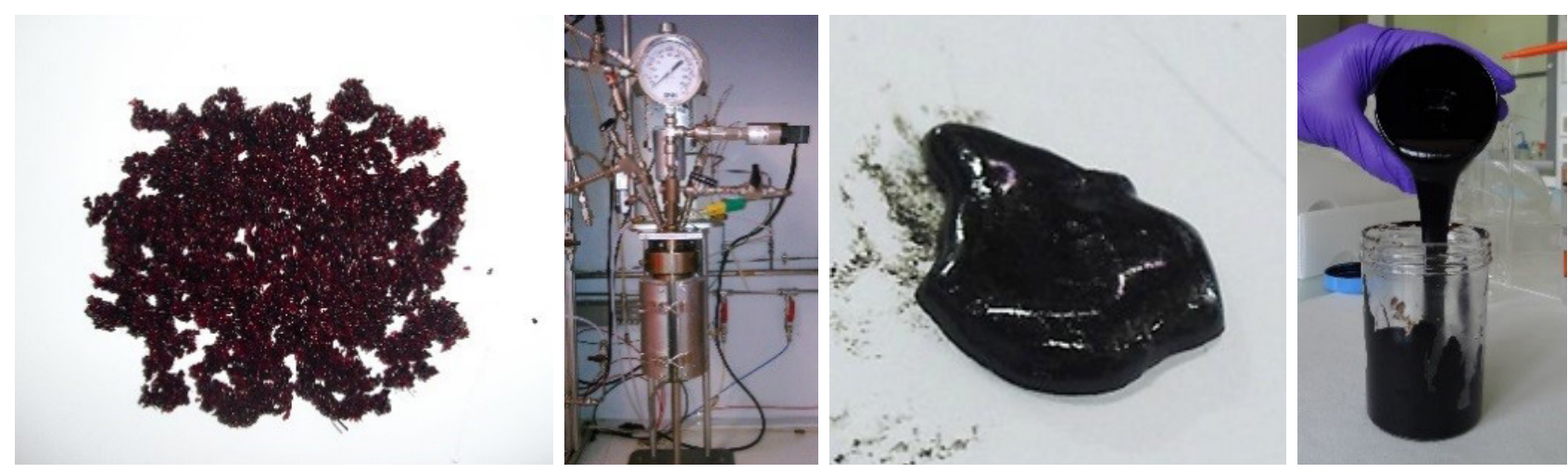

FIGURE 1: Example of the resource blackcurrant pomace, the HTL reactor and the obtained biocrude.

(Déniel at al., 2017). Important parameters include ash content, fibre composition and content, protein and lipids. This study presents results with biomasses rich in lipids and proteins but also with ligno-cellulosic biomasses. The differences in the results as well as the impact on the economic evaluation will be presented. It has been shown that certain additives (Deniel et al., 2017) and operating conditions (Déniel et al., 2016) also greatly influence biocrude and bio-oil yields but also their quality.

There are many technical-economic evaluations of biomass to fuel processes. There are however few evaluations of HTL processes, most on the conversions of biomass into biofuel. The majority of the evaluations of the HTL process are done on either algae (Hognon et al. 2015; Ou, Thilakaratne, Brown, \& Wright, 2015) or wood (Goudriaan \& Peferoen, 1990; Zhu et al., 2014). Other studies exist on swine manure as a resource (Buisonjé et al., 2010; Minarick et al., 2011). Typical production costs for diesel type fuels from cultivated algae are in the $2-3 € \mathrm{~L}^{-1}$ range (Hognon et al., 2015) considering a fully integrated production site. Prices of defatted (waste) algae are much lower as the extracted lipids are sold at a premium price. HTL fuels from defatted algae may be much cheaper, less than $1 € \mathrm{~L}^{-1}(\mathrm{Ou}$ et al., 2015) for very large plants (2000 tonne day $\left.{ }^{-1}\right)$. Wood conversion plants at a large scale are also expected to be (nearly) profitable at a large scale with production prices in the 0.6 to $1.2 € \mathrm{~L}^{-1}$ range (Goudriaan \& Peferoen, 1990; Zhu et al., 2014). More complicated feedstocks such as sewage sludge and swine manure received less attention for technical-economic evaluations of the HTL process. Buisonjé (Buisonjé et al., 2010) estimated that an integrated swine manure conversion plant should be economically viable with a gate fee of at least $15 €$ tonne $^{-1}$ applied to the wet swine manure to produce a biocrude that can be sold to a refinery for further upgrading.

Sewage sludge conversion in HTL plants has an additional challenge in that the resource is very distributed, available throughout the territory in small quantities. Transport of wet sludge over significant distances is not recommendable. Local processing should be favoured. The waste water treatment plant of a typical metropolitan area as Grenoble (France) produces around 7000 tonne of dry matter per year, around 1 tonne dry matter per hour, or around $10 \mathrm{~m}^{3}$ per hour of biomass slurry. This capacity is 10 to 100 times smaller than projected wood processing facilities and extremely small compared to fossil fuel refineries. There remain important uncertainties on the chemistry and technological issues on HTL plants. The optimal residence time in the reactor will probably range from 10 to 20 minutes depending on the resource and the temperature. This means that the reactor volume should be around $2.5 \mathrm{~m}^{3}$ which is already quite large for a pressurised reactor. Alternatively multiple smaller reactors in parallel could be considered. Being limited to low scales make economic viability even more difficult. Gate fees are common place in the waste treatment industry and typically 100 to $200 €$ tonne $^{-1}$ is charged for waste treatment in France (Awiplan, 2015). The use of sewage sludge as an agricultural resource is more and more constrained and is also costly (Ferry \& Wiart., 2002), with prices in the same range.

The focus of this paper is on wet solids wastes such as food processing residues and municipal sewage sludge. Many other resources are suitable for hydrothermal liquefaction, such as micro and macro algae or even dry resources such as wood. The actual resources presented in this study include grape marc and blackcurrant pomace representing food processing residues. Three types of sewage sludge were also tested, mixed, activated, and anaerobically digested sewage sludges. These resources are characterised by a humidity varying from 50 to $90 \mathrm{wt} . \%$ and an extremely variable chemical composition. The analysis of the resources is performed by following regular food analysis norms for fibres, lipids and proteins.

Hydrothermal liquefaction produces a biocrude with an interesting energy content. The biocrude can be further separated into bio-oil and char by means of solvent extraction. The produced oil can be compared to heavy fuel oil (Anouti, Haarlemmer, Déniel, \& Roubaud, 2016). This bio-oil can be further refined into a biofuel by catalytic upgrading, typically to produce a biodiesel (Zhu et al., 2014). The higher the degree of refinement considered, the more uncertain the technical and economic feasibility is.

The objective of this study is to show how these low value resources can be valorised and upgraded to biofuels. The paper presents experimental results of how different resources behave under hydrothermal liquefaction conditions. However, the emphasis of this paper is not on the 
experimental work. The product yields of different resources, converted at the same conditions, are used to estimate the cost of the hydrothermal conversion. Gate fees are estimated to ensure economic viability of the plants.

\section{MATERIALS AND METHODS}

\subsection{Materials and experimental procedure}

Food processing residues presented in this study are grape marc and blackcurrant pomace. These are procured via local producers (UNGDA and Les Vergers de Boiron). Additionally, three types of sewage sludge were tested, mixed, activated, and anaerobically digested sewage sludge from municipal waste water treatment plants (WWTP) in the Grenoble region in France (Aquantis in Voreppe and Aquapole in Le Fontanil).

The resources have been analysed by well-known techniques to establish the chemical composition of the resource. The results are presented in Table 1. Simple sugars cannot be quantified by standard methods and are typically calculated by difference (everything that is not ash, protein, lipid or fibre).

Experiments were performed in a $0.6 \mathrm{~L}$ stainless steel (SS316) stirred batch reactor (Parr Instruments Company). In a typical experiment, the reactor was filled with $240 \pm 5 \mathrm{~g}$ of biomass slurry, with a constant $14 \mathrm{wt} \%$ dry matter to water ratio in the case of blackcurrant pomace and grape marc. Sludge 1 was diluted to $10 \%$ dry matter to ensure good rheological properties. Sewage sludges 2 and 3 , were used as received. The autoclave was leak tested, purged and pressurised to $1 \mathrm{MPa}$ with nitrogen gas, to ensure sufficient pressure for gas analysis after the transformation. The pressure inside the reactor is a function of the reaction temperature, the amount of water and the amount of produced gas during the process. The reactor was stirred at $600 \mathrm{rpm}$ and was heated to the reaction temperature by an electrical heater. Once the reactor reaches the reaction temperature, it was held during a specified time (holding time) within $\pm 1^{\circ} \mathrm{C}$ of the specified operating temperature. For these experiments a 15 min holding time was applied. All resources have been treated at $300^{\circ} \mathrm{C}$, this temperature was reached in about 35 minutes. After the holding time, the reactor was rapidly cooled to room temperature in 20 min by an air quench.

After venting the reactor for gas analysis, the content of the reactor was first filtered on a Buchner filter to separate the aqueous phase from the raw organic residue. The raw organic residue (biocrude) was generally sticky, and removed from the reactor. The reactor was then weighed and the weight difference with the empty reactor is counted as raw organic residue. The produced biocrude, was dried at room temperature under air circulation until a stable mass was obtained (variation less than $0.1 \mathrm{mg}$ ). The experimental procedure is further detailed in the Figure 2.

The biocrude was separated into char and bio-oil using a solvent, ethyl-acetate in our case. Bio-oil was recovered after evaporation of the solvent at room temperature under air circulation, until a stable weight is obtained. GC-MS analysis confirmed that no residual solvent is left in the bio-oil. The char was also dried at room temperature under air circulation, until a stable weight was obtained. Weight loss of the char after extraction and drying was used to determine the proportion of solvent-soluble organics in the raw residue, and therefore the bio-oil yield. The bio-oil can alternatively be estimated by extraction from wet biocrude followed by solvent evaporation or by weighing the bio-oil after extraction. Determination of the water content by Karl-Fisher and comparison with the water content found by oven drying can provide an estimate to the amount of volatiles in the bio-oil that cannot be quantified otherwise. To limit the loss of volatile compounds the products are dried at room temperature. All yields reported in this study are expressed in weight percentage of the dry biomass (wt.\% dry matter).

TABLE 1: Characterisation of blackcurrant pomace, grape marc and sewage sludge used in this work.

\begin{tabular}{|c|c|c|c|c|c|}
\hline & Blackcurrant pomace & Grape marc (dried) & Sludge 1 Mixed & Sludge 2 Activated & Sludge 3 Digested \\
\hline Moisture content (wt.\%) ${ }^{1}$ & 59.6 & 7.4 & 83 & 94 & 97 \\
\hline HHV resource dry basis $\left(\mathrm{MJ} \mathrm{kg}^{-1}\right)$ & 18.5 & 23.3 & 20.1 & 19.6 & 14.6 \\
\hline Fibre content (wt.\% of dry matter) ${ }^{2}$ & 62 & 70 & 40 & 38 & 50 \\
\hline NDF (Neutral Detergent Fibres) & 62 & 70 & 40 & 38 & 50 \\
\hline ADF (Acid Detergent Fibres) & 53 & 63 & 28 & 30 & 26 \\
\hline ADL (Acid Detergent Lignin) & 35 & 49 & 21 & 7 & 18 \\
\hline Cellulose (ADF-ADL) & 18 & 15 & 7 & 23 & 8 \\
\hline Hemicelluloses (NDF-ADF) & 9 & 6 & 12 & 8 & 25 \\
\hline Lignin (ADL) & 35 & 48 & 21 & 7 & 18 \\
\hline Proteins (wt.\% of dry matter) ${ }^{3}$ & 17 & 9.7 & 11 & 5 & 3 \\
\hline Lipids (wt.\% of dry matter) ${ }^{4}$ & 15 & 8.1 & 10 & 15 & 13 \\
\hline Ash content at $550^{\circ} \mathrm{C}$ (wt. $\%$ of dry matter) ${ }^{5}$ & 4.3 & 4.8 & 14 & 14 & 38 \\
\hline \multicolumn{6}{|c|}{$\begin{array}{l}{ }^{1} \text { EN 14774-1 (AFNOR, 2010a) } \\
{ }^{2} \text { NF V18-122 (AFNOR, 2013) } \\
{ }^{3} \text { Kjeldahl method } \\
{ }^{4} \text { Hydrochloric acid digestion + Petroleum ether extraction } \\
{ }^{5} \text { NF EN } 14775 \text { (AFNOR, 2010b) }\end{array}$} \\
\hline
\end{tabular}




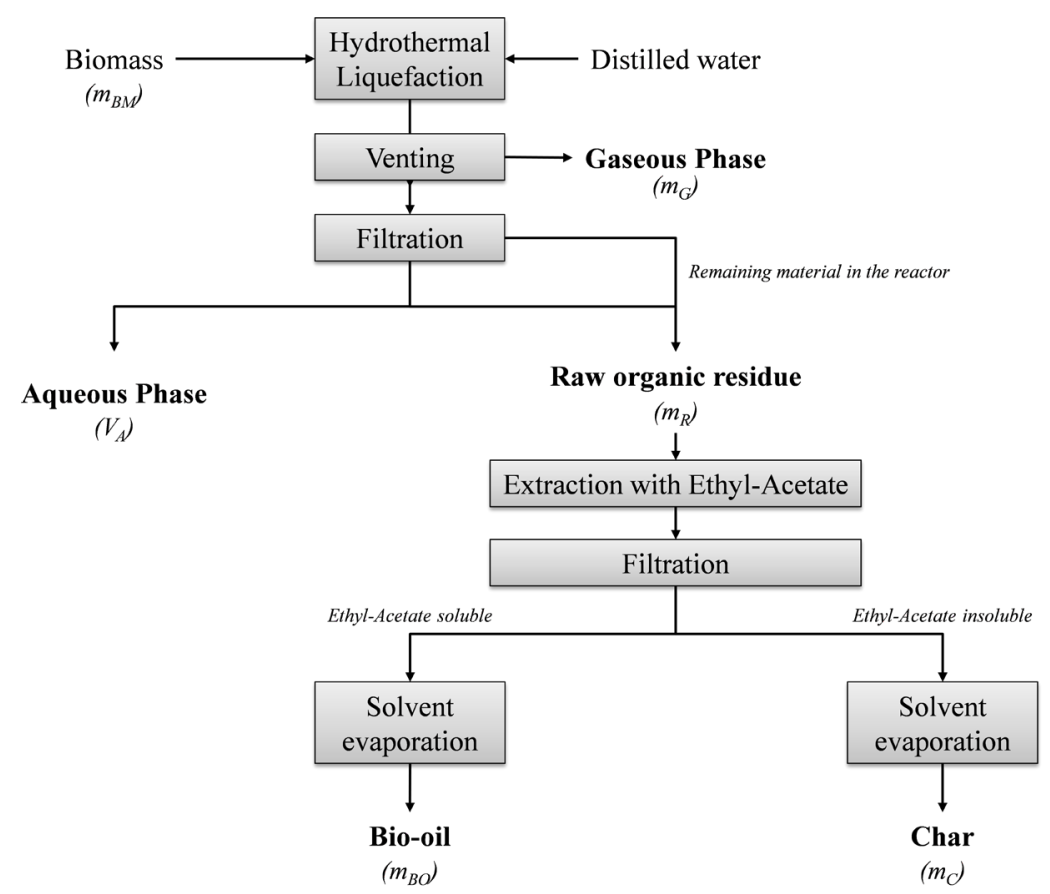

FIGURE 2: Products recovery procedure after hydrothermal liquefaction.

\subsection{Economic Evaluation}

The technical-economic evaluation is based on a process simulation with the ProSimPlus software (ProSim, 2012). The simulation was used to design the equipment in terms of heat exchange surfaces and electrical power. The evaluation of the equipment cost and economic evaluation is based on the methods described by Turton (Turton et al., 2003) and Chauvel (Chauvel et al., 2001). The main economic parameters as they enter in the production costs are presented in Table 2. The total installed equipment cost (Inside Battery Limits, ISBL) served as a basis to estimate the overall investment (CAPEX), including buildings, utilities, and engineering.

The approach was that the plant is located on an existing industrial site, either a food processing plant or a waste water treatment plant. The assumption was that the hydrothermal plant will be operated by an existing team of operators that is reinforced by one person for each shift. The capacity of the proposed plant was chosen to match an urban sewage treatment works of a city like Grenoble treating the water of 500000 inhabitants. This a common capacity, even though much large treatment works. The majority of treatment works are much smaller.

Discounted cash flow methods take into account the erosion of the value of the invested money and the value of the cash flow by discounting operating costs and revenues in time. A euro earned in 2017 has more value to a company as a euro in 2027 as profits earned earlier it can be reinvested early to earn more money. The cash flow (CF) in any operating year $\mathrm{n}$ is discounted to a "present value".

$C F_{n}=\frac{\text { Revenues }_{n}-\text { Costs }_{n}}{(1+D R)^{n}}$

The operation is evaluated as a project with a start, operation and a clearly defined ending. The sum of the discounted investment, all yearly cash flows and the salvage value (value of the plant after service) of the plant is the Net Present Value (NPV) of the project after $\mathrm{N}$ years. This means that the project has generated a return on investment equal to the discount rate.

$N P V=\operatorname{DeprCapCost}+\sum_{n=1}^{N} C F_{n}+\frac{\text { SalvageValue }}{(1+D R)^{N}}$

The minimum selling price is found by imposing the NPV to zero with a selected depreciation time.

Fixed costs consist of financial, personnel, maintenance and general overheads. The financial costs are essentially the costs of the bank loan. The cost of a Full Time Employee (FTE) is based on a French salary. With five

TABLE 2: Financial parameters for the economic evaluation.

\begin{tabular}{|c|c|}
\hline Parameter & Value \\
\hline Discount rate & 8\% (typical value) \\
\hline Interest rate bank loan & $5 \%$ (fixed) \\
\hline Part bank loan in investment & $50 \%$ \\
\hline Stream factor & 7000 h year $^{-1}$ \\
\hline Capital depreciation & 10 years \\
\hline Loan duration & 10 years \\
\hline Technical lifetime & 20 years \\
\hline Tax rate & $30 \%$ \\
\hline Personnel & 5 Full Time Employees (FTE) \\
\hline Personnel costs FTE & 70 k€ year $^{-1} \mathrm{FTE}^{-1}$ \\
\hline Electricity cost & $150 € \mathrm{MWh}^{-1}$ \\
\hline Treatment cost waste water & $0.5 € \mathrm{~m}^{-3}$ \\
\hline Salvage value plant & $10 \%$ du CAPEX \\
\hline
\end{tabular}


shifts, one operator specific to the HTL plant is added to each shift. Maintenance and overheads are proportional to the size of the plant (and therefore its cost) and are typically estimated from a percentage of the CAPEX, $4 \%$ in our case. Variable costs include electricity usage and the cost of water treatment. Even recycled locally in the treatment works, the process water will generate some additional costs.

In this study we assumed that the products have a negative value and that the producer is prepared to pay for their disposal. In our case, the WWTP will internally shift funds from the disposal to the HTL unit. Taking into account this additional revenue allows the sale of the products on the general market at the price of fossil fuels. For all cases a gate fee was calculated to lower the production costs to match fossil fuel market prices.

\section{EXPERIMENTAL RESULTS}

Hydrothermal experiments always produced a mixture of solids (char), extractable (bio-oil) and an aqueous phase rich in ash and organic molecules. The products were separated according to the procedure described earlier. The results of the experiments are presented in Table 3.

As mentioned in section 2, the bio-oil yield can be evaluated by different methods. Drying of the biocrude or evaporating an extraction solvent always entrain the loss of light volatile compounds. Comparing the water content in the wet biocrude after filtration obtained by Karl-Fisher titration and that obtained by oven drying effectively showed that volatiles are lost in the drying and evaporation process. In practice for the blackcurrant pomace, $4 \%$ of initial dry ash free biomass was converted in bio-oil without being detected as such. We presented earlier (Anouti et al., 2016) a very detailed analysis of the bio-oil obtained from blackcurrant pomace.

We observed significant variations between the results from the different resources. Resources rich in lipids and proteins such as sewage sludge but also blackcurrant pomace produce significant amounts of oil. The lipids initially present in the resource clearly help increasing the biooil yield. The lignin rich grape marc produced less oil than the other resources under these conditions. Digested sewage sludge was very rich in ash and as a consequence contains less organic material. In addition, the organic material remaining after anaerobic digestion contains few proteins and lipids. It has lost much of its proteins and lipid content, making it less interesting for HTL.

Some of the sulphur was found in the gas phase as hydrogen sulphide. The produced gas was rich in $\mathrm{CO}_{2}$, but it did contain some hydrocarbons and badly smelling molecules. The gas needs to be oxidised in a fired heater before it can be vented to atmosphere. The aqueous phase contains a significant amount of organics and cannot be disposed without further treatment. The process water must be treated before disposal.

\section{TECHNO-ECONOMIC EVALUATION}

The technical-economic analysis is presented on these five resources. Two different cases are presented. A simple conversion plant that produces biocrude that is sold to a refinery as a crude oil replacement. In the second case, the same conversion plant is equipped with a solvent extraction unit to produce a bio-oil. Bio-oils are corrosive due to their high acidity (Anouti et al., 2016; Haarlemmer et al., 2016). This means that stainless steel should be used as construction material.

The water content positively affects the results of the liquefaction, it has been shown that increasing dry matter content decreases the oil yields of the process (Déniel et al., 2016; Yang et al., 2016). However, increasing the water content also increases the volume of the installations. The water content in the feed is $90 \mathrm{wt} \%$ (10 wt.\% dry matter) for this evaluation to obtain sufficiently good rheological properties for sludge 1 . This ensures good pumpability and optimal yields. The sewage sludge is very wet when produced and can easily be dewatered to the desired water content. Grape marc and blackcurrant pomace is much dryer when produced and will have to be diluted with process water. This actually has a beneficial effect on the yield and the biocrude quality (Déniel et al., 2016).

The biocrude plant is described in Figure 3 . The plant consists of a two major subunits, these are the biocrude production unit and a separation unit that separates biocrude into bio-oil and char. Most (80\%) of the required heat is recovered from the product stream in heat exchangers HX1 and HX2. The products are sticky when cold. Full heat recovery is therefore problematic as heat exchangers tend to foul when the biocrude contacts cold surfaces. Some additional heating ( $20 \%$ of the total heat requirement) is therefore necessary on feed of the HTL Reactor (two reactors are required to model the reactions). This is done by burning char or some of the produced biocrude in the

TABLE 3: Results of batch liquefaction experiments at $300^{\circ} \mathrm{C}$.

\begin{tabular}{|c|c|c|c|c|c|}
\hline Yields & Blackcurrant pomace & Grape marc & Sludge 1 Mixed & Sludge 2 Activated & Sludge 3 Digested \\
\hline Biocrude (\%) & 52 & 35 & 51 & 61 & 54 \\
\hline HHV / LHV Biocrude $\left(\mathrm{MJ} \mathrm{kg}^{-1}\right)$ & $32 / 30$ & $30 / 28$ & $26 / 24$ & $24 / 23$ & $13 / 12$ \\
\hline Char (wt.\%) & 27 & 22 & 27 & 35 & 37 \\
\hline Bio-oil (wt.\%) & 25 & 13 & 24 & 26 & 17 \\
\hline HHV / LHV Bio-oil (MJ kg-1) & $33.4 / 31.3$ & 34 / 32 & $33 / 31$ & Not Available & Not Available \\
\hline Gas (wt.\%) & 12 & 8.0 & 5.5 & 8.5 & 6.6 \\
\hline Aqueous phase (by difference) (wt.\%) & 24 & 57 & 44 & 31 & 40 \\
\hline
\end{tabular}




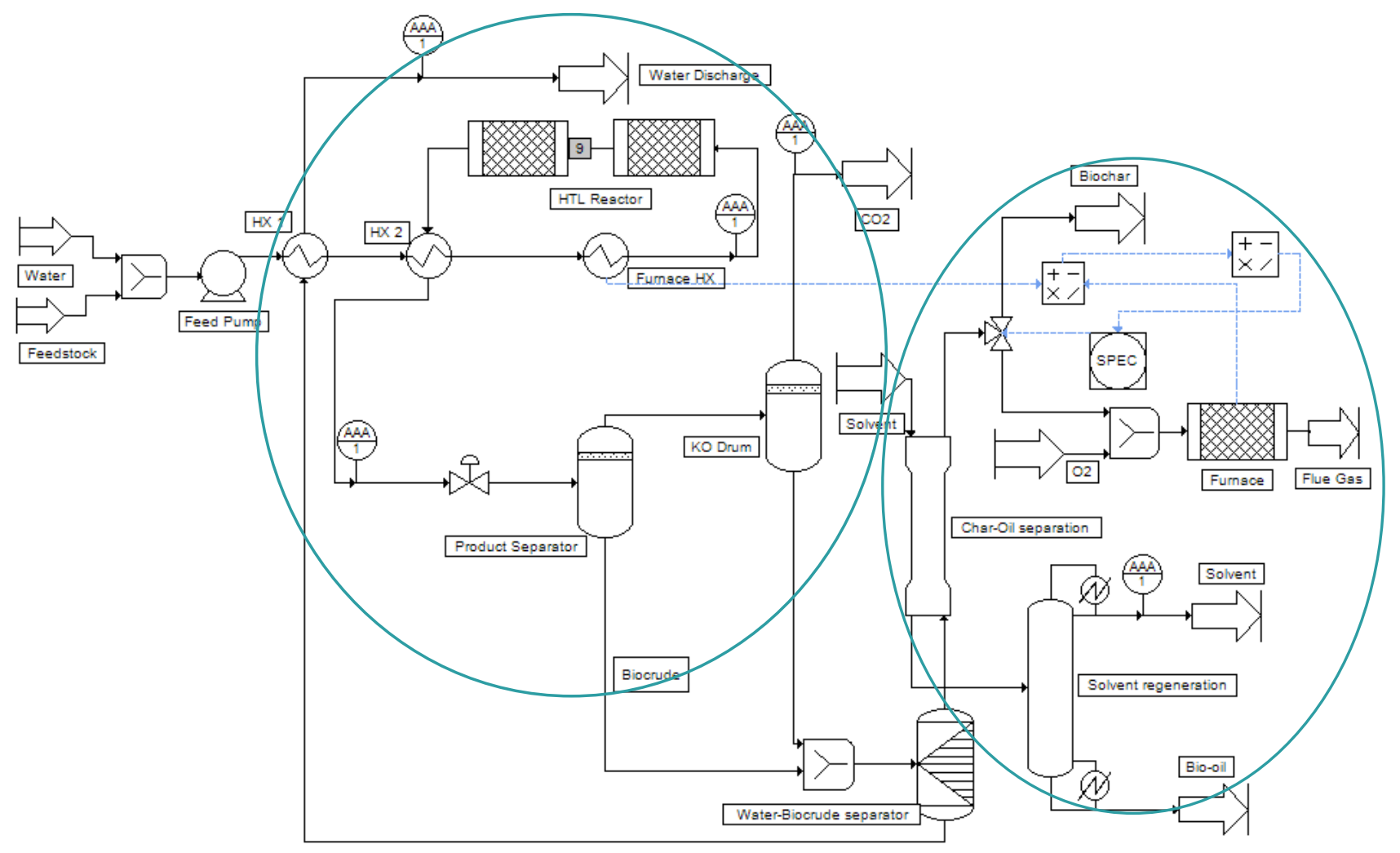

FIGURE 3: Process scheme biocrude and bio-oil plant.

Furnace. The consumption of these products is taken into account in the economic evaluation.

The HTL reactor converts the feed into a biocrude. The residence time is assumed to be 15 minutes. The products are cooled by heating the feed and the aqueous phase, the biocrude and the gas are separated in the Product Separator and the Water-Biocrude Separator. The biocrude should be maintained above $60^{\circ} \mathrm{C}$ to prevent plugging. Water is recycled into the process as much as possible or purged. The purged water is recycled or discharged to the waste water treatment plant, not included in the process diagram. There are some costs associated with this. Globally, the amount of water is not very large, proportional to the water entering the system. In the case of sewage sludge, the process water is locally reprocessed. The waste water treatment works in Grenoble process $240,000 \mathrm{~m}^{3}$ per day, while the corresponding HTL plant would produce $240 \mathrm{~m}^{3}$ per day. In the case of the blackcurrant pomace and grape marc process water is sent to external water treatment plant leading to additional costs in these cases.

\subsection{Biocrude plant}

The different resources were evaluated and presented below in Table 4 . Biocrude is produced by processing a biomass slurry. In this study we assumed the same heat of reaction for all biomasses. The amount of biomass pumped, heated and products cooled having the same volume, the cost of the plant is insensitive to the actual biomass type. As the volumes of treated slurry are the same, the investment costs are the same. Fixed and operating costs are also the same between the different cases as they are estimated from a fixed percentage of the capital costs. The differences are in the yields and the energy content of the products. A gate fee is calculated in the cases when the biocrude production costs are higher than the reference crude oil price. The gate fee is the negative value of the feed to make sure the products can be sold without further losses. When the gate fee is lower than alternative disposal ways, the operation is beneficial. The heating values used for the energy equivalence are reported in Table 3.

The precision of the reported data does not correspond to the actual precision of the estimations. CAPEX estimations are notoriously difficult and uncertain early in the development of a technology. Typical uncertainties are in the $50 \%$ range or even higher at this stage (Dysert, 2003). Economic evaluations largely depend on business plans and on the economic structure of the exploiting organisation. The methods and results presented in this paper are fairly standard but variations exist. For these reasons it is difficult to quantify the precision of the presented results.

\subsection{Bio-oil plant}

The second case concerns the same plant extended with a solvent extraction unit to separate the biocrude into bio-oil and char as shown in Figure 3. A solvent is mixed into the biocrude stream to dissolve the bio-oil. Char is separated from the mixture as an insoluble part in the CharOil Separator. The solvent is separated from the bio-oil by distillation. The biocrude contains insoluble char, heavy oil but also light compounds (Anouti et al., 2016; Haarlemmer 
et al., 2016). In practice, the initial solvent will be rapidly replaced by the light compounds included in the biocrude that are separable by distillation.

The different resources were evaluated and are presented in Table 5. The investment costs are now dependant on the amount of oil produced. The production costs only concern the oil produced, the char is used as fuel for the process and is not further valorised. The heating values used for the energy equivalence are reported in table 3 . For sludges 2 and 3 the heating value of sludge 1 were used.

The results show that the production costs of hydrothermal oil and vegetable oils are very similar. They are both significantly more expensive than fossil fuel oil. There remains a major issue with the quality differenc- es between the products. Fuel oils are refined products ready for use. Vegetable oils need some upgrading, but this process is well understood. Hydrothermal oils are probably slightly too viscous and acidic to directly replace heavy fuel oil. The actual market value of these oils are unknown.

\subsection{Comparison with existing practices}

Table 6 presents an overview of the gate fees required for economic viability for both solutions. These calculated values are compared to typical values found for waste incineration and agricultural use of sewage sludge. Hydrothermal liquefaction, combined with the sales of biocrude or bio-oil, can indeed be economically viable. The work shows that gate fees are comparable to current waste incineration

TABLE 4: Results of the economic evaluation of an HTL biocrude plant.

\begin{tabular}{|c|c|c|c|c|c|}
\hline & Blackcurrant pomace & Grape Marc & Sludge 1 & Sludge 2 & Sludge 3 \\
\hline Investment (CAPEX) - M€ & \multicolumn{5}{|c|}{5.55} \\
\hline Heat Exchangers & \multicolumn{5}{|c|}{0.86} \\
\hline Pumps & \multicolumn{5}{|c|}{0.70} \\
\hline Reactor & \multicolumn{5}{|c|}{1.30} \\
\hline Storage & \multicolumn{5}{|c|}{0.35} \\
\hline Utilities and terrain & \multicolumn{5}{|c|}{1.79} \\
\hline Electricity consumption - MW & 0.3 & 0.3 & 0.3 & 0.3 & 0.3 \\
\hline Fixed costs - M€ year ${ }^{-1}$ & 0.61 & 0.61 & 0.61 & 0.61 & 0.61 \\
\hline Variable costs - M€ year-1 & 0.35 & 0.35 & 0.35 & 0.35 & 0.35 \\
\hline Minimum selling price - $€$ tonne ${ }^{-1}$ & 462 & 787 & 494 & 383 & 598 \\
\hline Minimum selling price - $€ \mathrm{GJ}^{-1}$ & 14.4 & 26.3 & 19.0 & 12 & 46.0 \\
\hline Gate fee - $€$ tonne ${ }^{-1}$ dry matter & 108 & 154 & 131 & 89 & 173 \\
\hline Crude oil (Brent 2015) - € GJ-1 & \multicolumn{5}{|c|}{6.7} \\
\hline Fossil coal (2015) - € GJ-1 & \multicolumn{5}{|c|}{1.5} \\
\hline
\end{tabular}

TABLE 5: Results of the economic evaluation of an HTL bio-oil plant.

\begin{tabular}{|c|c|c|c|c|c|}
\hline & Blackcurrant pomace & Grape Marc & Sludge 1 & Sludge 2 & Sludge 3 \\
\hline Investment (CAPEX) - M€ & 6.53 & 6.36 & 6.50 & 6.56 & 6.30 \\
\hline Heat Exchangers & 0.86 & 0.86 & 0.86 & 0.86 & 0.86 \\
\hline Pumps & 0.70 & 0.70 & 0.70 & 0.70 & 0.70 \\
\hline Reactor & 1.30 & 1.30 & 1.30 & 1.30 & 1.30 \\
\hline Storage & 0.35 & 0.35 & 0.35 & 0.35 & 0.35 \\
\hline Utilities and terrain & 1.90 & 1.90 & 1.90 & 1.90 & 1.90 \\
\hline Bio-oil extraction & 0.42 & 0.25 & 0.39 & 0.45 & 0.19 \\
\hline Electricity consumption - MW & 0.35 & 0.35 & 0.35 & 0.35 & 0.35 \\
\hline Fixed costs - M€ year ${ }^{-1}$ & 0.81 & 0.79 & 0.81 & 0.81 & 0.72 \\
\hline Variable costs - M€ year-1 & 0.56 & 0.56 & 0.56 & 0.56 & 0.56 \\
\hline Minimum selling price $-€$ tonne $^{-1}$ & 1040 & 1990 & 1083 & 1000 & 1390 \\
\hline Minimum selling price - $€ \mathrm{GJ}^{-1}$ & 30 & 57 & 31 & 29 & 40 \\
\hline Gate fee - $€$ tonne ${ }^{-1}$ dry matter & 202 & 228 & 204 & 200 & 196 \\
\hline Heavy Fuel Oil - € GJ-1 & \multicolumn{5}{|c|}{9.4} \\
\hline Domestic Fuel Oil - $€ \mathrm{GJ}^{-1}$ & \multicolumn{5}{|c|}{15} \\
\hline Crude Palm Oil - $€$ GJ $^{-1}$ & \multicolumn{5}{|c|}{17 (September 2017) } \\
\hline Soy Bean Oil - € GJ-1 & \multicolumn{5}{|c|}{30 (September 2017) } \\
\hline
\end{tabular}


TABLE 6: Comparison between established gate fees and the projected gate fees in this study.

\begin{tabular}{|c|c|c|c|c|c|}
\hline & Blackcurrant pomace & Grape Marc & Sludge 1 & Sludge 2 & Sludge 3 \\
\hline \multicolumn{6}{|l|}{ Biocrude } \\
\hline Gate fee - $€$ tonne ${ }^{-1}$ dry matter & 108 & 154 & 131 & 89 & 173 \\
\hline Gate fee - $€$ tonne ${ }^{-1}$ wet & 44 & 77 & 22 & 5 & 5 \\
\hline \multicolumn{6}{|l|}{ Bio-Oil } \\
\hline Gate fee - $€$ tonne ${ }^{-1}$ dry matter & 202 & 228 & 204 & 200 & 196 \\
\hline Gate fee - $€$ tonne ${ }^{-1}$ wet (hum) & $82(60 \%)$ & $114(50 \%)$ & $35(83 \%)$ & $12(94 \%)$ & $6(97 \%)$ \\
\hline $\begin{array}{l}\text { Typical agro sludge disposal } \\
\text { (Ferry \& Wiart., 2002) }\end{array}$ & \multicolumn{5}{|c|}{$200-400 €$ tonne $^{-1}$ dry matter or $25-100 €$ tonne $^{-1}$ wet at $75 \%$ humidity } \\
\hline $\begin{array}{l}\text { Waste incineration } \\
\text { (ADEME, 2015) }\end{array}$ & \multicolumn{5}{|c|}{$200-300 €$ tonne $^{-1}$ dry matter or $100-150 €$ tonne $^{-1}$ wet at $50 \%$ humidity } \\
\hline
\end{tabular}

plants, in the range of 100 to $150 €$ per tonne of wet waste. The organic matter has a typical humidity of $50 \mathrm{wt} . \%$ leading to a cost of 200 to $300 €$ per tonne of dry matter. Agricultural sludge disposal costs typically between 200 and $400 €$ per tonne of dry matter. Hydrothermal liquefaction costs are at the low end of agricultural disposal costs.

As is was mentioned before it seems rather unpractical to have large plants, beyond 1 to 10 tonne dry matter per hour. Small scale production facilities, close to the resources such as food processing factories and population centres appear to be an obvious application for hydrothermal liquefaction. Economic viability will necessarily come via gate fees to compensate for these relatively small capacities. Figure 4 presents the required gate fee for the treatment of blackcurrant pomace as a function of the production capacity for the two case studies.

Figure 4 shows that the required gate fee increases (due to increasing production costs) rapidly with decreasing production capacity. The reference point are placed well below the typical incineration or agro disposal fees so even with escalating construction costs the plant may still be viable.

\section{CONCLUSIONS}

Food processing wastes and sewage sludge are interesting carbonated resources. Rather than looking for low value valorisation, more value can be added to these waste steams by hydrothermal liquefaction. The technology is not able to compete economically with the fossil energy industry. Most organic waste producers are used to pay to dispose of these waste. The cost varies greatly with the nature of the waste and with the local legislation. With gate fees in the 50 to $130 €$ tonne $^{-1}$ dry matter range hydrothermal liquefaction can produce liquid fuels that can compete with fossil fuels. Significant uncertainties subsist however about the quality of the fuels and their compatibility with existing applications.

Not all resources are however equally suited for this technology. The results are however variable and optimal conditions need to be found for each resource. Lignin rich resources such as grape marc yield much lower oil yields at low temperatures. These resources should be processed

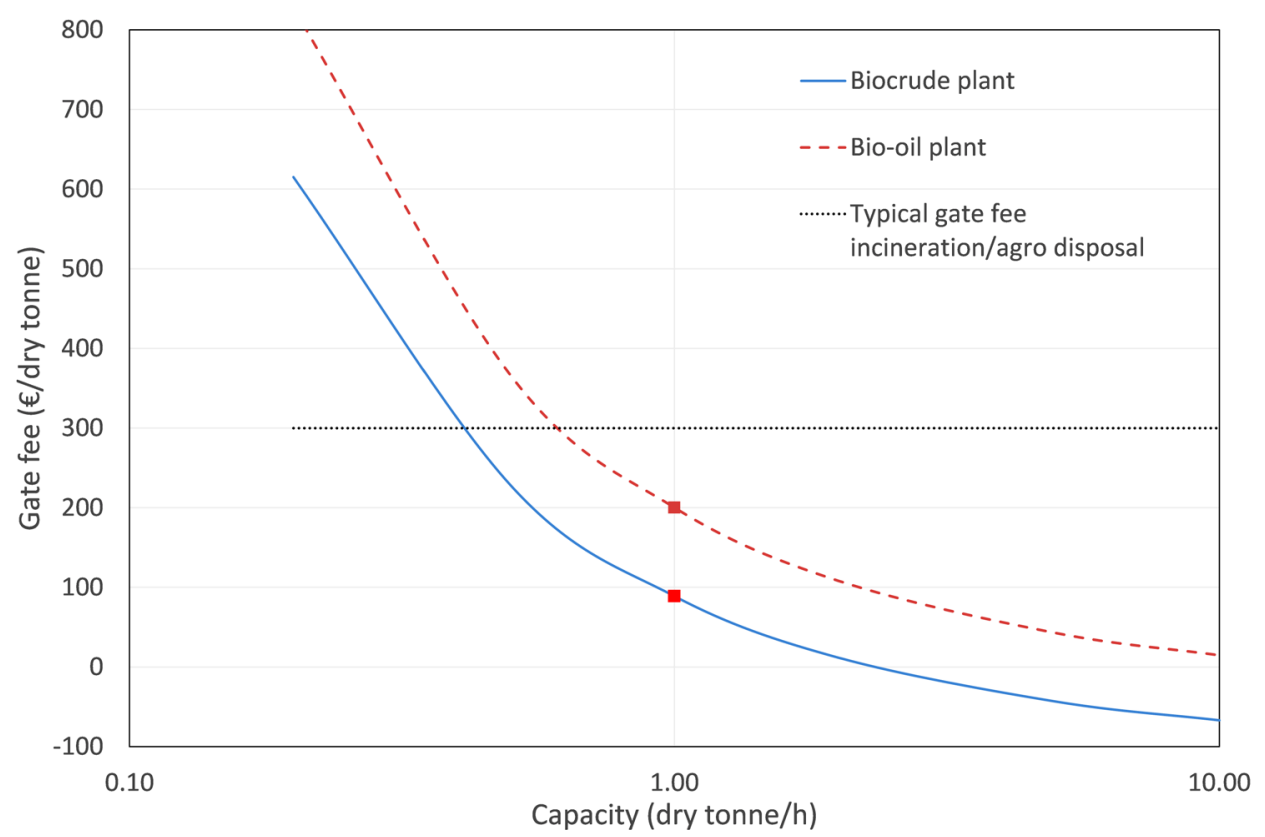

FIGURE 4: Sensitivity of the gate fees to the production capacity for the blackcurrant pomace resource (reference cases indicated with $\mathbf{}$ ) 
at higher temperatures (Pedersen et al., 2016). High ash resources, low in organic material such as digested sewage sludge are less interesting. The oil yields are low and the biocrude is of low quality as it is very rich in inorganic material.

\section{ACKNOWLEDGEMENTS}

The authors would like to acknowledge financial support from the French Research National Agency ANR (LIQHYD project. Grant No. ANR-12-BIME-0003). The authors are also grateful to Marine Blanchin, Hélène Miller and Sébastien Thiery for technical support and help on analysis of the products. We also like to thank UNGDA, Les Vergers Boiron, Aquapole and Aquantis for their supply of our resources.

\section{REFERENCES}

ADEME. (2015). Referentiel National des coûts du service public de gestion des déchets.

Afnor, NF EN 14774-1 Biocombustibles solides - Détermination de la teneur en humidité - Méthode par séchage à l'étuve - Partie 1 : humidité totale - Méthode de référence (2010a).

Afnor, NF EN 14775 Biocombustibles solides - Méthode de détermination de la teneur en cendres (2010b).

Afnor, NF V18-122 - Aliments des animaux - Détermination séquentielle des constituants pariétaux - Méthode par traitement aux détergents neutre et acide et à l'acide sulfurique (2013).

Anouti, Suzanne, Haarlemmer, Geert, Déniel, Maxime, \& Roubaud, Anne. (2016). Analysis of Physicochemical Properties of BioOil from Hydrothermal Liquefaction of Blackcurrant Pomace. Energy \& Fuels, 30(1), 398-406. doi: 10.1021/acs.energyfuels. 5 b02264

Awiplan. (2015). Referentiel national des coûts du service public de gestion des déchets en 2012. Angers: ADEME - Service Mobilisation et Valorisation des Déchets.

Buisonjé, F.E. de, Bergsma, E.J., Zeevalkink, J.A., \& Melse, R.W. (2010). Feasibility of HTU for manure processing. Wageningen: Wageningen University.

Chauvel, A ., Fournier, G., Raimbault, C., \& Pigeyre, A. (2001). Manuel d'évaluation économique des procédés. Paris: Editions Technip.

Déniel, M., Haarlemmer, G., Roubaud, A., Weiss-Hortala, E., \& Fages, J. (2016). Bio-oil Production from Food Processing Residues: Improving the Bio-oil Yield and Quality by Aqueous Phase Recycle in Hydrothermal Liquefaction of Blackcurrant (Ribes nigrum L.) Pomace. Energy\&Fuels, 30(6), 4895-4904. doi: http://pubs.acs. org/doi/abs/10.1021/acs.energyfuels.6b00441

Deniel, Maxime, Haarlemmer, Geert, Roubaud, Anne, Weiss-Hortala, Elsa, \& Fages, Jacques. (2017). Hydrothermal liquefaction of blackcurrant pomace and model molecules: understanding of reaction mechanisms. Sustainable Energy \& Fuels, 1, 555-582. doi: 10.1039/C6SE00065G
Déniel, Maxime, Haarlemmer, Geert, Roubaud, Anne, Weiss-Hortala, Elsa, \& Fages, Jacques. (2016). Optimisation of bio-oil production by hydrothermal liquefaction of agro-industrial residues: blackcurrant pomace (Ribes nigrum L.) as an example. Biomass and Bioenergy, 95, 273-285. doi: http://dx.doi.org/10.1016/j.biombioe.2016.10.012

Dysert, L. (2003). Sharpen Your Cost Estimating Skills. Cost Engineering, 46(6), 22-30.

Elliott, Douglas C., \& Schiefelbein, Gary F. (1989). Liquid Hydrocarbon fuels from biomass Division of Fuel Chemistry Annual Meeting Preprints (Vol. 34, pp. 1160-1166): American Chemical Society.

Ferry, M., \& Wiart., J. (2002). Coûts de la filière d'utilisation agricole des boues d'épuration municipales. Ingénieries - EAT, 30, 59-69.

Goudriaan, F., \& Peferoen, D.G.R. (1990). Liquid fuels from biomass via a hydrothermal process. Chemical Engineering Science, 45(8), 2729-2734.

Haarlemmer, Geert, Guizani, Chamseddine, Anouti, Suzanne, Déniel, Maxime, Roubaud, Anne, \& Valin, Sylvie. (2016). Analysis and comparison of bio-oils obtained by hydrothermal liquefaction and fast pyrolysis of beech wood. Fuel, 174, 180-188. doi: http://dx.doi. org/10.1016/j.fuel.2016.01.082

Hognon, Céline, Delrue, Florian, \& Boissonnet, Guillaume. (2015). Energetic and economic evaluation of Chlamydomonas reinhardtii hydrothermal liquefaction and pyrolysis through thermochemical models. Energy, 93, Part 1, 31-40. doi: http://dx.doi.org/10.1016/j. energy.2015.09.021

Kruse, Andrea, \& Dahmen, Nicolaus. (2015). Water - A magic solvent for biomass conversion. The Journal of Supercritical Fluids, 96(0), 36-45. doi: http://dx.doi.org/10.1016/j.supflu.2014.09.038

Minarick, Mitchell, Zhang, Yuanhui, Schideman, Lance, Wang, Zhichao, Yu, Guo, Funk, Ted, \& Barker, Doug. (2011). Product and Economic Analysis of Direct Liquefaction of Swine Manure. BioEnergy Research, 4(4), 324-333. doi: 10.1007/s12155-011-9157-z

Ou, Longwen, Thilakaratne, Rajeeva, Brown, Robert C., \& Wright, Mark M. (2015). Techno-economic analysis of transportation fuels from defatted microalgae via hydrothermal liquefaction and hydroprocessing. Biomass and Bioenergy, 72(0), 45-54. doi: http://dx.doi. org/10.1016/j.biombioe.2014.11.018

Pedersen, T. H., Grigoras, I. F., Hoffmann, J., Toor, S. S., Daraban, I. M., Jensen, C. U., Rosendahl, L. A. (2016). Continuous hydrothermal co-liquefaction of aspen wood and glycerol with water phase recirculation. Applied Energy, 162, 1034-1041. doi: http://dx.doi. org/10.1016/j.apenergy.2015.10.165

ProSim. (2012). ProSimPlus 3. Toulouse, France: ProSim.

Turton, Richart, Bailie, BRichard C., Whiting, Wallace B., \& Shaeiwitz, Joseph A. (2003). Analysis, Synthesis and Design of Chemical Processes (2nd ed.). New Jersey, USA: Prentice Hall.

Yang, Linxi, Nazari, Laleh, Yuan, Zhongshun, Corscadden, Kenneth, Xu, Chunbao, \& He, Quan. (2016). Hydrothermal liquefaction of spent coffee grounds in water medium for bio-oil production. Biomass and Bioenergy, 86, 191-198. doi: http://dx.doi.org/10.1016/j.biombioe.2016.02.005

Zhu, Yunhua, Biddy, Mary J., Jones, Susanne B., Elliott, Douglas C., \& Schmidt, Andrew J. (2014). Techno-economic analysis of liquid fuel production from woody biomass via hydrothermal liquefaction (HTL) and upgrading. Applied Energy, 129, 384-394. doi: http:// dx.doi.org/10.1016/j.apenergy.2014.03.053 